Rok XVI (2021) | 1 (31) | S. 321-334

https://doi.org/10.12797/LV.16.2021.31.26

Ewa Kubusiak •

Uniwersytet Jagielloński, Kraków

ewa.kubusiak@uj.edu.pl

\title{
LEKSYKA PRZESTĘPCZA W TRYLOGII ZłODZIEJSKIEJ SERGIUSZA PIASECKIEGO
}

Słowa klucze: socjolekt przestępczy, Sergiusz Piasecki, trylogia przestępcza

Keywords: criminal sociolect, Sergiusz Piasecki, criminal trilogy

\section{Informacje wstępne}

Języki grup społecznych od lat stanowią ciekawy materiał badawczy, który nieustannie się zmienia i znacznie różni się od polszczyzny ogólnej. Są one przedmiotem zainteresowania wielu badaczy, w tym także lingwistów, którzy stają przed nie lada wyzwaniem: jest nim rzetelne zebranie i opracowanie odpowiednich danych. Dla badacza jako dla osoby spoza grupy odmiany te przynajmniej na początku pozostają w znacznej mierze niezrozumiałe. Jednym ze sposobów, by odtajnić to, co jest zaszyfrowane i przeznaczone tylko dla wybranych, dla członków danej grupy, jest wniknięcie w środowisko używające danego języka. Dzięki ludziom, którzy tego dokonują, możemy zidentyfikować i opisać wiele zjawisk językowych - zwłaszcza w zakresie leksyki czy frazeologii - które pochodzą z tych odmian i które pozostawiły ślady w polszczyźnie.

Jedną z bardziej interesujących odmian naszego języka jest ta używana przez ludzi należących do półświatka przestępczego. Ulega ona ciągłym przeobrażeniom i w miarę upływu czasu jej stare wersje stają się coraz bardziej niezrozumiałe dla współczesnych użytkowników. Być może zapomniany zostałby również przedwo- 
jenny język przestępców z Kresów Wschodnich, gdyby w literaturze nie pojawił się Sergiusz Piasecki. Należał on do środowiska przestępczego i przeżywał przygody, o których napisał później w swojej „trylogii złodziejskiej”, posługując się socjolektem przestępczym. Język ten odgrywa podwójną rolę: $z$ jednej strony uatrakcyjnia treść powieści, nadaje jej autentyczności i niepowtarzalnego klimatu, a z drugiej stanowi słownik „szemranego” środowiska przedwojennych przestępców.

Trylogia złodziejska, w której skład wchodzą trzy powieści: Jabłuszko (Piasecki 1990a), Spojrze ja w okno (Piasecki 199ob) i Nikt nie da nam zbawienia (Piasecki 199oc), opowiada o losach zawodowego złodzieja, Aleksandra Barana, oraz jego kolegów po fachu. Akcja toczy się w latach 1918-1919 w Mińsku Litewskim. We wstępie do trylogii Piasecki pisze, że Mińsk jako miasto przyfrontowe był skupiskiem złodziei „z najrozmaitszych dzielnic dawnego imperium rosyjskiego", dlatego też wyrazy stosowane przez tamtejszych przestępców pochodzą z różnych regionów (Piasecki 1990a: 7). Chociaż Piasecki, pisząc powieści i używając w nich autentycznej dla tego okresu leksyki złodziejskiej, opierał się na własnych doświadczeniach z przeszłości, żadna z jego książek nie znalazła się w spisie źródeł Słownika gwar przestępczych Klemensa Stępniaka z 2013 r., na co zwrócił uwagę Tadeusz Szczerbowski (2018: 117).

We wstępie do „trylogii” Piasecki pisze:

Te trzy powieści [...] nie są amoralne. Może pewni ludzie pokuszą się, by nazwać je akademią przestępstw. W tym wypadku ja nazwę je akademią zwalczania przestępstw i przestępców zawodowych przez poznanie ich życia, zwyczajów, „filozofii”, „etyki” i metod pracy... Przestępcy zawodowi o „frajerach” wiedzą wszystko. „Frajerzy” o nich mało. Przestępcom moje książki są zbędne. Psychologów, kryminologów nauczą wiele (Piasecki 1990a: 7).

Wstęp pełni ważną funkcję w tej powieści. Autor wyjaśnia w nim czytelnikowi cel swojej książki oraz usprawiedliwia jej tematykę. Ponadto wciela się w rolę swego rodzaju przewodnika po leksyce złodziejskiej, choć zastrzega, że nie jest językoznawcą i nie specjalizuje się w znajomości tego socjolektu, ale zna go z autopsji (ibid.). Ciekawe, że Piasecki posługuje się leksyką złodziejską nie tylko w samej powieści, ale również we wstępie, czego przykładem w powyższym cytacie jest rzeczownik frajer. W dalszej części wprowadzenia do utworu autor wyjaśnia, że główni bohaterowie to postaci autentyczne, a „przygody w połowie rzeczywiste” (ibid.: 8). Pisze: „Jest tam sporo fantazji, lecz nie ma nic z próżni. Wszystko powstało z czegoś, co przeżyłem w więzieniach lub na wolności" (ibid.).

Warto w tym miejscu przyjrzeć się postaci autora, którego przeszłość jest znacząca zarówno dla treści, jak i dla języka trzech książek.

Sergiusz Piasecki to pisarz urodzony w 1901 r. na Białorusi, wychowywany przez ojca Polaka w kulturze rosyjskiej. Od urodzenia znał tylko języki rosyjski i białoruski, z polszczyzną nie miał styczności aż do dwudziestego roku życia. Uczęszczał do rosyjskich szkół, jednak bardzo szybko zrezygnował z nauki na rzecz przestępczego 
życia. Nie wszystkie rabunki i przemyty kończyły się sukcesem, toteż Piasecki zaczął w konsekwencji odbywać kary więzienne.

Ostatnim punktem, do jakiego trafił, było więzienie na Świętym Krzyżu. Wtedy właśnie zajął się literaturą. Impulsem do pisania stał się dla niego list od ojca, który zachęcił go do opowiadania „o ludziach mających oryginalne charaktery i przeżywających niezwykłe przygody" (cyt. za: Polechoński 2000: 37).

W 1929 r. na Świętym Krzyżu Piasecki zaczął uczyć się języka polskiego, jego specyficznej, więziennej odmiany. Dostęp do literatury miał znikomy. Początkowo uczył tylko na podstawie „Wiadomości Literackich”, gdzie zwracał szczególną uwagę na budowę zdań. Zaczął pisać nieliczne wiersze, w końcu spod jego pióra wyszła pierwsza powieść, Piąty etap, fabularyzowany reportaż oparty na przygodach z czasów działalności wywiadowczej. Następnie w 1935 r. Piasecki napisał Kochanka Wielkiej Niedźwiedzicy, pamiętnikarską opowieść o przemytnikach.

Podczas drugiej wojny światowej początkujący pisarz służył w oddziałach Armii Krajowej, a w 1945 r., aby przeżyć, wybrał emigrację. Gdy przebywał na obczyźnie, we Włoszech, wydał tak zwaną „trylogię złodziejską”, którą napisał podczas wojny na Wileńszczyźnie. Następnie przeniósł się do Hastings w Wielkiej Brytanii, gdzie pracował i tworzył do końca swojego życia. Zmarł w 1964 r. ${ }^{1}$

$\mathrm{W}$ powieściach Piaseckiego słownictwo przestępcze występuje nie tylko w dialogach, w rozmowach między bohaterami złodziejami. Pojawia się też w narracji, szczególnie w drugiej części trylogii, w której Piasecki, jak zdradził we wstępie, postanowił nie ograniczać się w użyciu języka środowiskowego. Pragnął wiernie przedstawić wspólnotę, posługującą się tym językiem, zgodnie z tym, w jaki sposób sam ją zapamiętał. Możliwe, że zadbanie o autentyczność przekazu było podstawowym celem pisarza. Fakt ten potwierdzają odautorskie wtrącenia do tekstu właściwego powieści, nie do końca trafione, jeśli chodzi o literackość utworu, natomiast przydatne w celu zrozumienia pewnych osobliwości środowiska przestępczego.

Utrwalenie języka w powieściach - jego funkcjonowanie w narracji oraz w wypowiedziach bohaterów - jest bardzo ciekawym zjawiskiem. Oprócz odmiany literackiej języka polskiego pojawia się u Piaseckiego autentyczny dialekt północnokresowy ${ }^{2}$, w którym występują zapożyczenia z języków rosyjskiego i białoruskiego. Również specyficzny język środowiskowy - socjolekt złodziei - obecny na płaszczyźnie leksykalnej zawiera wiele elementów tego dialektu³.

1 Szczegółową biografię Sergiusza Piaseckiego przedstawili Krzysztof Polechoński (2000) i Ryszard Demel (2001).

2 Jak pisze Zofia Kurzowa, „dialekt północnokresowy to odmiana języka ogólnego, odznaczająca się zespołem innowacji w rozwoju tego języka, wytworzonych w procesie asymilacyjnym do obcego substratu językowego, upowszechnionych w obrębie zbiorowości polskiej zamieszkującej etnicznie obce terytorium białoruskie i litewskie" (Kurzowa 2006: 74).

3 O roli dialektu północnokresowego w kształtowaniu się socjolektu pisałam w innym artykule (por. Kubusiak 2018). 
Termin socjolekt jest przedmiotem wielu językoznawczych i socjologicznych sporów, ugruntował się już jednak na dobre we współczesnych teoriach socjolingwistycznych dzięki Aleksandrowi Wilkoniowi (1987) jako określenie na odmianę języka narodowego związaną z istnieniem jakiegoś środowiska lub grupy społecznej. Wilkoń, omawiając języki środowiskowe, zaznaczył, że granica pomiędzy profesjolektem a socjolektem jest nieostra, jednak przedstawił kryteria, które pozwalają zdefiniować socjolekt i odróżnić go od profesjolektu. Grupy społeczne, które porozumiewają się socjolektem, charakteryzują się: silnymi więzami wewnętrznymi (zawodowymi, kulturowymi, towarzyskimi), względną stabilnością, silnym poczuciem odrębności w stosunku do innych grup, ciągłością tradycji, częstotliwością kontaktów członków grupy nieograniczoną do kontaktów zawodowych ${ }^{4}$ (por. ibid.: 94).

Stanisław Milewski pisze, że socjolekty przestępcze rodziły się i kształtowały zawsze tam, gdzie skupiały się środowiska ludzi żyjących z kradzieży lub wykonujących inne podejrzane zajęcia. Historycy zauważają ich istnienie w różnych epokach i krajach, począwszy od średniowiecza. Zdaniem autora książki Szemrane towarzystwo niegdysiejszej Warszawy:

slangi przestępcze $[. .$.$] nie były raczej tworzone jako konwencjonalne języki tajne$ [...]. Ich ezoteryczność brała się z tego, że grupy posługujące się na co dzień tym słownictwem żyły w dobrowolnej izolacji..., uprawiając przestępczy proceder, stawiały się poza społeczeństwem [...] (Milewski 2009: 137-138).

Według S. Milewskiego środowiska przestępcze cementowała mentalność przejawiająca się w języku: negatywny, pogardliwy stosunek do „frajerów” i „psów” znajdował wyraz w nacechowanych emocjonalnie epitetach. Jak pisze dalej Milewski: „głównie ta barwa emocjonalna sprawia, że język złodziejski jest także nośnikiem wartości i wyobrażeń będących zaprzeczeniem społecznych norm etycznych" (ibid.).

Warto dodać, że w skład socjolektu złodziejskiego wchodziły zapożyczenia z języków obcych, m.in. z hebrajskiego, jidysz, niemieckiego, rosyjskiego, greckiego, ukraińskiego, łacińskiego, francuskiego (Uł: 47) oraz tureckiego (Reychman 1965: 154). Nie było ich jednak aż tak dużo, jak mogłoby się wydawać: najwięcej elementów leksykalnych pochodziło z polszczyzny, jak pisze Henryk Ułaszyn (Uł: 47). Agnieszka Małocha (1994: 136) dodaje, że zapożyczenia z języków obcych, czyli poniekąd odizolowanych od języka polskiego, sprzyjały kształtowaniu się socjolektu przestępczego jako odmiany niezrozumiałej przez społeczeństwo. Wiele elementów leksy-

4 Badania A. Wilkonia kontynuowali m.in.: Stanisław Grabias (1997), Tomasz Piekot (2008), Ewa Kołodziejek (2015). Zdaniem S. Grabiasa w każdym socjolekcie istnieją obok siebie (w różnym natężeniu) funkcje: profesjonalno-komunikatywna i ekspresywna. Badacz wyróżnił trzy zasady, które organizują słownictwo i różnicują socjolekty: 1) zawodowość, 2) tajność, 3) ekspresywność (Grabias 1997: 146). Ewa Kołodziejek wymieniła z kolei cechy odróżniające socjolekty od języka ogólnego i potocznego. Są to: nowość leksykalna i frazeologiczna, synonimy, tautonimy, metafory, dowcip językowy, zmienność leksyki, okazjonalizmy, indywidualizmy (Kołodziejek 2015: 18). 
kalnych socjolektu przestępczego to tak zwane internacjonalizmy, to znaczy wyrazy wspólne wielu językom. Jest to świadectwo językowe przemieszczania się przestępców po różnych częściach Europy i wymiany elementów leksykalnych wchodzących w skład języka tej grupy społecznej. Internacjonalizmy występują nie tylko w polskiej odmianie socjolektu przestępczego, ale również np. w ukraińskiej czy rosyjskiej, o czym świadczą opracowanie Argo w Ukraini Oleksy Gorbacza (2006) oraz Slovar' tûremno-lagerno-blatnogo žargona (Bal'daev, Belko, Isupov 1992).

\section{Analiza materiału}

Podstawę materiałową badań stanowiły trzy tomy „trylogii złodziejskiej” S. Piaseckiego. Interesowały mnie wyrazy tekstowe, wyrażenia, zwroty należące do socjolektu przestępczego. Wydzieliłam 235 elementów językowych, które reprezentują następujące części mowy: rzeczowniki, czasowniki, przymiotniki, przysłówki, wyrażenia przyimkowe. Podczas ekscerpcji przykładów zwracałam uwagę na to, czy w bliższym lub dalszym otoczeniu leksykalno-składniowym występuje objaśnienie znaczenia elementu językowego. Ponadto rozpatrywałam, czy element językowy należy do warstwy przedmiotowej, obejmującej wypowiedzi bohaterów oraz trzecioosobową narrację, czy też do poziomu strategii nadawczo-odbiorczej tekstu (Labocha, Tutak 2005: 20), zwłaszcza do jego obudowy paratekstowej ${ }^{5}$ (Loewe 2007). Zgromadzoną leksykę złodziejską podzieliłam na grupy, korzystając z prób kategoryzacji Henryka Ułaszyna (Uł) i Macieja Raka $(2016)^{6}$. Klasyfikacje zaproponowane przez tych dwóch badaczy obejmują swoją tematyką także słownictwo zaczerpnięte z powieści Piaseckiego. Objaśnienia znaczeń rekonstruowałam na podstawie kontekstu powieściowego. Wielokrotnie, gdy było to możliwe, uwzględniałam „definicje” stworzone przez S. Piaseckiego, zawarte $\mathrm{w}$ odautorskim paratekście oraz $\mathrm{w}$ samych powieściach. Zebrany materiał zestawiłam z opracowaniami leksykograficznymi: Seweryna Udzieli (Żargon złodziejski we Lwowie, 1892 r., za: Rak 2016, dalej: Ud), Antoniego Kurki (Słownik mowy złodziejskiej, 1899 r., dalej: K), Karola Estreichera (Szwargot więzienny, 1903 r., dalej: E), Wiktora Ludwikowskiego i Henryka Walczaka (Żargon mowy przestępców „Blatna muzyka”, 1922 r., dalej: LW) oraz Henryka Ułaszyna (Język złodziejski, 1951 r., dalej: Uł). Opracowania leksykograficzne pochodzą z lat 1892-1951. Zdecydowałam się na uwzględnienie wymienionych słowników dlatego, że czas ich publikacji odpowiada czasowi akcji powieści oraz życia S. Piaseckiego.

5 Chodzi o takie elementy paratekstowe, jak: wstęp, odautorskie słowniki zamieszczone na końcu każdej powieści oraz przypisy pochodzące od autora.

6 Maciej Rak (2016: 136) w przypisie 3 odnotował, że siatkę pól leksykalnych nazw złodziei z monografii H. Ułaszyna zrekonstruował S. Grabias $(1997,2010)$. Odpowiada ona materiałowi leksykalnemu zebranemu przeze mnie na podstawie powieści Piaseckiego. 
Analiza materiału polegała na wymienieniu i przyporządkowaniu do poszczególnych kategorii haseł wraz z ich znaczeniem. Odpowiednimi skrótami zostały opatrzone potwierdzenie hasła i jego znaczenia przez słowniki. Pogrubioną czcionką oznaczono te hasła, które występują tylko u Piaseckiego i ich znaczenie nie jest poświadczone w opracowaniach leksykograficznych.

Wydzieliłam następujące kategorie:

\section{Nazwy osób:}

\section{Złodzieje:}

a) określenia złodziei, czyli synonimy słowa „złodziej”: blatny LW 137 , K 8, Uł 59, E 40, blatniak LW 13, K 8, Uł 59, E 40, chapun, farmazon, fartowiec LW 24, Uł 32, fartowy LW 24, Uł 32, firmowy, grojse ganef Uł 32, swój LW 67, Uł 32, woryga, żygan 'złodziej';

b) typy złodziei ze względu na sposoby dokonywania rabunków: aferzysta (aferzystka) 'złodziej uczestniczący w aferach'; chipisznik (chipisznica), doliniarz (doliniara) Ud 135, E 46, LW 21, Uł 33, K 10 'złodziej kieszonkowy'; giganciarz 'złodziej pracujący w kilku specjalnościach naraz'; grandziarz LW 28 'złodziej dokonujący napadu rabunkowego'; hołociarz/połociarz LW 30, Uł 33 'złodziej trzody'; klawisznik LW 37, E 58, Uł 34 'złodziej włamujący się do mieszkań za pomocą narzędzi'; potokarz LW 59, Uł 33, K 20, E 113 'złodziej okradający wozy'; pudlarz LW 6o, Uł 33 'złodziej okradający sejfy'; skokier LW 63, Uł 33 'złodziej okradający mieszkania'; styrocznik 'złodziej okradający podczas gry w karty'; szopenfeldziarz (szopenfeldziara) LW 69, K 24, Uł 33 'złodziej okradający sklepy'; sznifer/szniferz LW 68, Uł 34 'złodziej okradający mieszkania w nocy'; torbochwat 'złodziej kradnący torby na ulicy, zwykle kobietom'; tufciarz 'oszust targowy'.

\section{Ludzie, którzy współpracują ze złodziejami:}

czarnogietdziarz, paser (paserka) K 24, E 70, LW 55 'osoba sprzedająca nielegalnie kradzione przedmioty'; meliniarz (meliniara) LW 47 'właściciel meliny'; reks, ścianka LW 62, E 76, K 21, Uł 40, świeca LW 67, Uł 34, tucer (tucerka) LW 73, Uł 34 'osoba stojąca na czatach'.

\section{Ofiary złodziei:}

balon, dzwon, fiej LW 24, frajer (frajerka) E 49, K 49, LW 25, gad, hartapan, karaś, luj, szkop, szpaniuga 'człowiek, który nie jest złodziejem'; cham LW 17, żłob LW 79 'chłop'; chuligan 'rozrabiaka, który nie jest złodziejem'; ciepły, do-

7 Liczby przy skrótach oznaczają numery stron. 
lator (dolatorka) LW 21 'osoba okradana'; szamtrapa 'ludzie z marginesu społecznego'; szmaciarz 'osoba pogardzana przez złodziei'; szpagat 'inteligent'.

\section{Przeciwnicy złodziei:}

barbos, pies LW 56, Uł 39 'policjant'; hint LW 30, Uł 39, legawy ${ }^{8}$ LW 43, Uł 39, męta/menta E 66, LW 47, K 17, Uł 39 'policjant, dozorca'; moser LW 48, Uł 39, 'dozorca'; kapuś LW 34, K 14, Uł 42, E 56 'donosiciel'.

\section{Kobiety':}

dryzda LW 21 'dziewczyna (obraźliwie)'; dziewczynka 'prostytutka'; ksiuta, marucha LW 46, Uł 32, szmara LW 68, Uł 32, wydra 'kobieta'; lafirynda, szlucka, ścierka LW 62 'kobieta (obraźliwie)'; szyksa 'ładna dziewczyna'.

\section{Inne:}

chabal LW 91, E 43 'kawaler'; wystawny LW 51, Uł 41 'osoba ukrywająca się przed policją'; żminda 'skąpy człowiek'.

\section{Grupy złodziejskie:}

chewra LW 17, K 9, Uł 49, ferajna LW 24, sitwa LW 63, Uł 40 'grupa złodziejska'.

\section{Przedmioty:}

\section{Rzeczy ukradzione:}

awantyż, barachło LW 12, Uł 35, facjenta LW 23, E 47, K 10, Uł 35, majdan LW 45, Uł 35 'nieokreślone rzeczy ukradzione’; cebula LW 16, E 45, Uł 36, K 9, bimber LW 13, Uł 36 'zegarek'; blit LW 14, Uł 35 'złoto'; ciuchy LW 18, E 44, Uł 36, szmokty 'ubrania'; kusz LW 42, Uł 35 'przedmioty o dużej wartości’; pajęczyna LW 54, E 70, K 19, Uł 36 'bielizna'; sarmak 'pieniądze'; szkiełko LW 68, Uł 35 'brylanty'.

\section{Narzędzia:}

mesel, statki LW 66, Uł 39, szaber LW 67, E 80, K 23, Uł 38, szpilard, szperak (szpyrak) LW 69, K 24, Uł 39, E 82, wierówka, wytrych LW 66, K 24, Uł 38, żaba LW 79 'narzędzie służące do włamywania'; siedemdziesiąt siedem rzeczy 'narzędzia służące do włamywania, ogólnie'; pietruwa LW 56, E 71, K 20, Uł 40 'kłódka'.

8 Jako słownikowe potwierdzenie danego hasła potraktowałam również tzw. dublety formalne (za: Uł: 39-40) - hasła, które w słowniku przyjmują nieco inną postać (występuje w nich alternacja samogłoskowa lub spółgłoskowa), ale znaczenie jest to samo, co u Piaseckiego, np. legawy - ligawy, kierny - kirny, tucer - tycer, dryzda - dryrda.

9 Zdecydowałam się wydzielić tę kategorię ze względu na to, że kobiety odgrywają istotną rolę w życiu powieściowych bohaterów. 


\section{Broń:}

komin LW 39, kopyto LW 40, spluwa LW 65, E 79 'rewolwer'.

\section{Inne:}

bibuła 'gazeta'; gryps LW 28, E 52, K 12 'list, notatka, tajna wiadomość z więzienia'; hamira/hamiza/hamita 'wódka'; kluft LW 38, Uł 36 'ubranie'; ksiba LW 41, K 16, Uł 50 'list'; lipa 'podróbka, sfałszowany przedmiot lub dokument'; potok LW 59, E 73, K 20 'wóz'; pudło LW 6o, Uł 36 'sejf, kasa'; skoki LW 63, E 78, Uł 36 'buty'; wstążi 'zniszczone ubranie'.

\section{Części ciała:}

finfa, kinol LW 36, E 57 'nos'; graba LW 28, E 51, K 11 'ręka'; japa, micha 'twarz'; pedały 'nogi'; sagan 'pośladki'.

\section{Typy rabunków:}

afera 'poważny rabunek, często z negatywnymi konsekwencjami'; chipisz, dolina LW 21, K 10, E 46, Uł 37, szyrma LW 71, Uł 33 'kradzież kieszonkowa'; gastrola 'kradzież podczas wyjazdu'; granda LW 28, E 51, Uł 38, stopka 'napad rabunkowy'; mojka LW 48, Uł 37 'kradzież; potokarstwo LW 50, Uł 37 'okradanie wozów'; robota LW 61, praca 'okradanie'; robota na fotografa, na gut morgen LW 99, Uł 33, na dzień dobry LW 99, Uł 37 'kradzież palt z mieszkań o poranku', na kabar 'włamanie się przez piwnicę lub strych', na kluczyk Uł 38 'okradanie mieszkania, gdy nie ma w nim właściciela', na maszynkę 'oszukanie ofiary poprzez rzekome demonstracje maszynki do mnożenia pieniędzy, w efekcie kradzież pieniędzy', na sobaczke 'uśpienie ofiary w celach rabunkowych', na wuja 'udawanie dalekiego krewnego ofiary w celu wywołania zamieszania po to, aby ją okraść', „w czerwone $\boldsymbol{i}$ czarne” 'oszustwo podczas gry karcianej w „czerwone i czarne”; skok LW 63, E 78, K 22, Uł 37 'okradanie mieszkania’; sznif LW 68, Uł 37, E 81 'okradanie mieszkania w nocy’; szop/szopenfeld LW 69, Uł 37 'kradzież sklepowa'.

\section{Miejsca:}

\section{Kryjówki złodziei:}

chaza E 43 'dom, chata'; chutor, melina LW 47, Uł 37 'mieszkanie, dom'; spelunka, truszczoba 'knajpa, w której złodzieje załatwiają swoje interesy i porachunki'.

\section{Inne:}

kicz LW 35, Uł 41 'więzienie'; łokciówka 'sklep z materiałami’; pająk LW 54, E 7o, Uł 37 'sklep'. 


\section{Działania:}

\section{Określenia kradzieży:}

chapnąć, zatyryć/zatyrać 'ukraść'; blatować LW 14, myć LW 73, operować, rąbać, robić LW 61 'kraść'; robić $\boldsymbol{w y d r e ̨ ~ ' k r a s ́ c ́ ~ d u z ̇ o , ~ z ~ s u k c e s e m ' ; ~ z a h a m a c ́ ~}$ 'ukraść część łupów wspólnikowi'; chodzić po szyrmie LW 71, Uł 33 'kraść z kieszeni'; obrabiać LW 54, brać (np. na wuja) LW 76, uprawiać (np. dolinę) 'okradać, często za pomocą określonego sposobu'.

\section{Określenia ucieczki:}

dawać gwinta, drałować, drapać, drefić, nogować, piętować, plitować LW 57, K 20, Uł 41, E 100, urywać LW 61, Uł 41, zwiewać LW 74, Uł 41 'uciekać'.

3. Określenia stania na warcie:

być świeca LW 67, cynkować/stać na cynku LW 49, Uł 40, stać na lipku LW 50, Uł 40, stać na stromie Uł 34 'stać na warcie’.

4. Określenia uprzedzania o niebezpieczeństwie:

dać abcyng LW 10, Uł 40, dać cynk LW 19, dać zeks LW 78, Uł 40 'uprzedzić o niebezpieczeństwie’.

\section{Pozostałe działania związane $z$ fachem złodziejskim:}

kitować (nakitować/zakitować) LW 77, K 14, E 57 'umierać'; maglować 'przekonywać do czegoś, kłamiąc'; melinować się LW 47 'ukrywać się w melinie'; nadać, sypnąć LW 67, K 26, Uł 40 'donieść; nadać LW 49, wystawiać robote LW 31, Uł 39 'przekazać komuś kradzież'; obłowić się LW 52, E 98 'wiele zyskać na kradzieży'; opylić 'sprzedać kradziony towar'; położyć, wkrochmalić się 'dać się złapać'; pruć LW 57, E 100 'strzelać'; przyszyć sprawę 'oskarżyć bez dowodów'; pucować się LW 60 'przyznawać się’; wsypać się Uł 40 'przypadkowo się ujawnić'.

\section{Inne:}

bajzować, glamać, stukać, trajlować LW 72, trzepać 'mówić'; bujać 'kłamać'; chodzić na pikietę 'świadczyć usługi seksualne na ulicy’; kiernaćc K 14, Ud 140, E 88, LW 36 'napić się, najczęściej wódki'; kimać LW 36, Ud 142, E 93, K 14, Uł 54 'spać'; podwalać się 'nachalnie podrywać kogoś'; puszczać dymy 'podrywać kogoś'; rozpuścić chody 'iść'; spartolić 'zepsuć'; szmajdnąć 'uderzyć'; wyźwirzyć się 'odwrócić się'; zajechać, zalakować 'uderzyć'; zapychać, pruć LW 59, E 101, Uł 41 'iść'; związać 'złapać'. 


\section{Nazwy określające:}

cytrynowy 'smutny'; kierny K 14, Ud 140, E 111, LW 36 'pijany'; starowny 'ładny, dobrze zbudowany'; trefny 'kradziony'; do luftu 'źle'; klawo LW 37, K 15, E 112, Ud 141 'dobrze'; na wytysz LW 51 'jawnie, otwarcie'; na zycher 'na pewno'; pod hajrem / pod chajrem 'słowo honoru'.

\section{Pozostałe hasła ${ }^{10}$ :}

chabar 'łapówka'; chipisz LW 30 'przeszukanie’; dintojra 'sąd złodziejski’; dola LW 21 'część z podziału zdobyczy przypadająca na jedną osobę'; jus 'zwierzęta domowe (bydło)'; glik 'szczęście'; mortus LW 48 'brak pieniędzy'; poruta LW 58, Uł 40 'nieprzyjemna sytuacja'; skower LW 64 'pies'; szocher 'niebezpieczeństwo'; szwindel E 82 'oszustwo'; wierchówka/wierzchówka 'kieszenie zewnętrzne'; wsypa 'ujawnienie działalności przestępczej'.

Potwierdzenie autentyczności materiału pochodzącego z powieści S. Piaseckiego Jabłuszko, Spojrze ja w okno i Nikt nie da nam zbawienia można znaleźć w wymienionych wcześniej opracowaniach leksykograficznych. Jednak nie wszystkie hasła znajdują swoje poświadczenie w słownikach. Co więcej, podane w słownikach definicje niektórych leksemów różnią się od ich znaczeń utrwalonych w powieści ${ }^{11}$ w takich sytuacjach nie uznawałam hasła występującego w słowniku za poświadczenie leksemu z trylogii złodziejskiej. Znaczenie musiało być tożsame z powieściowym lub do niego zbliżone. W poniższej tabeli zestawiłam wartości liczbowe i procentowe haseł poświadczonych oraz niepoświadczonych w słownikach wraz z podziałem na kategorie.

\begin{tabular}{lccc}
\multicolumn{1}{c}{ Nazwa zbioru } & $\begin{array}{c}\text { Łączna liczba } \\
\text { haseł w zbiorze }\end{array}$ & $\begin{array}{c}\text { Hasła poświadczo- } \\
\text { ne w słownikach }\end{array}$ & $\begin{array}{c}\text { Hasła występujące } \\
\text { tylko u Piaseckiego }\end{array}$ \\
\hline $\begin{array}{l}\text { Określenia złodziei, czyli synonimy } \\
\text { słowa „złodziej” }\end{array}$ & 12 & $6(50,00 \%)$ & $6(50,00 \%)$ \\
$\begin{array}{l}\text { Typy złodziei ze względu na sposoby } \\
\text { dokonywania rabunków }\end{array}$ & 15 & $10(66,67 \%)$ & $5(33,33 \%)$ \\
$\begin{array}{l}\text { Ludzie, którzy współpracują ze } \\
\text { złodziejami }\end{array}$ & 7 & $5(71,43 \%)$ & $2(28,57 \%)$ \\
\hline $\begin{array}{l}\text { Ofiary złodziei } \\
\text { Przeciwnicy złodziei }\end{array}$ & 18 & $5(27,78 \%)$ & $13(72,22 \%)$ \\
\hline
\end{tabular}

10 Leksemy zebrane w tej kategorii nie mieszczą się w innych wydzielonych przeze mnie grupach.

11 Jako przykład może posłużyć leksem pająk: w powieści, w słowniku Piaseckiego oraz u Ludwikowskiego i Walczaka jest to 'sklep', natomiast pozostałe opracowania podają znaczenia takie jak: 'żołnierz policyjny', 'policjant', 'dozorca więzien', 'tłumok', 'tkacz', 'koszula'. Trzy ostatnie znaczenia miałyby wiele wspólnego z pajęczyną, czyli 'bielizną’. 


\begin{tabular}{lccc}
\multicolumn{1}{c}{ Nazwa zbioru } & $\begin{array}{c}\text { Eączna liczba } \\
\text { haseł w zbiorze }\end{array}$ & $\begin{array}{c}\text { Hasła poświadczo- } \\
\text { ne w słownikach }\end{array}$ & $\begin{array}{c}\text { Hasła występujące } \\
\text { tylko u Piaseckiego }\end{array}$ \\
\hline Kobiety & 10 & $4(40,00 \%)$ & $6(60,00 \%)$ \\
\hline Inne osoby & 3 & $2(66,67 \%)$ & $1(33,33 \%)$ \\
\hline Grupy złodziejskie & 3 & $3(100,00 \%)$ & $0(0,00 \%)$ \\
\hline Rzeczy ukradzione & 13 & $10(76,92 \%)$ & $3(23,08 \%)$ \\
\hline Narzędzia & 10 & $6(60,00 \%)$ & $4(40,00 \%)$ \\
\hline Broń & 3 & $3(100,00 \%)$ & $0(0,00 \%)$ \\
\hline Inne przedmioty & 10 & $6(60,00 \%)$ & $4(40,00 \%)$ \\
\hline Części ciała & 7 & $2(28,57 \%)$ & $5(71,43 \%)$ \\
\hline Typy rabunków & 23 & $12(52,17 \%)$ & $11(47,83 \%)$ \\
\hline Kryjówki złodziei & 5 & $2(40,00 \%)$ & $3(60,00 \%)$ \\
\hline Inne miejsca & 3 & $2(66,67 \%)$ & $1(33,33 \%)$ \\
\hline Określenia kradzieży & 13 & $6(46,15 \%)$ & $7(53,85 \%)$ \\
\hline Określenia ucieczki & 9 & $3(33,33 \%)$ & $6(66,67 \%)$ \\
\hline Określenia stania na warcie & 4 & $4(100,00 \%)$ & $0(0,00 \%)$ \\
\hline $\begin{array}{l}\text { Określenia uprzedzania o niebezpie- } \\
\text { czeństwie }\end{array}$ & 3 & $3(100,00 \%)$ & $0(0,00 \%)$ \\
\hline $\begin{array}{l}\text { Pozostałe działania związane z fa- } \\
\text { chem złodziejskim }\end{array}$ & 15 & $9(60,00 \%)$ & $6(40,00 \%)$ \\
\hline Inne działania & 20 & $4(20,00 \%)$ & $16(80,00 \%)$ \\
\hline Nazwy określające & 9 & $3(33,33 \%)$ & $6(66,67 \%)$ \\
\hline Pozostałe hasła & 13 & $6(46,15 \%)$ & $7(53,85 \%)$ \\
\hline Ogółem & 235 & $122(51,91 \%)$ & $113(48,09 \%)$ \\
\hline
\end{tabular}

Na podstawie przedstawionych danych możemy stwierdzić, że największy rozdźwięk między liczbą haseł poświadczonych w słownikach a niepoświadczonych ${ }^{12}$ występuje w kategoriach: ludzie, którzy współpracują ze złodziejami, przeciwnicy złodziei, grupy złodziejskie, rzeczy ukradzione, broń, określenia stania na warcie, określenia uprzedzania o niebezpieczeństwie (na korzyść haseł poświadczonych w słownikach) oraz: ofiary złodziei, części ciała, inne działania (na korzyść haseł występujących tylko u Piaseckiego). W pozostałych kategoriach liczba haseł poświadczonych i niepoświadczonych jest podobna. Ogólem potwierdzonych haseł jest 122 (51,91\%), a niepotwierdzonych 113 (48,09\%).

12 Biorę pod uwagę różnicę około czterdziestu (i więcej) punktów procentowych. 


\section{Podsumowanie}

Zestawienie w tabeli pokazuje, że ponad połowa haseł z „trylogii złodziejskiej” została odnotowana w opracowaniach leksykograficznych, począwszy od Żargonu złodziejskiego we Lwowie S. Udzieli z 1892 r., skończywszy na Języku złodziejskim H. Ułaszyna z 1951 r. Warto zwrócić uwagę na to, że aż 113 haseł (48,09\%) występuje wyłącznie w "trylogii złodziejskiej” ${ }^{13}$ - hasła te nie pojawiają się w wybranych przeze mnie opracowaniach leksykograficznych. Można zatem potraktować Jabłuszko, Spojrze ja w okno i Nikt nie da nam zbawienia jako nowe źródło poznania wyrazów socjolektu przestępczego, które wcześniej nie zostały utrwalone ${ }^{14}$, a Piaseckiego jako znawcę środowiska złodziei, którego był członkiem, oraz języka, jakim to środowisko się posługiwało.

Największą liczbę potwierdzonych haseł można odnaleźć w słowniku W. Ludwikowskiego i H. Walczaka Żargon mowy przestępców „Blatna muzyka” z 1922 r. - jest ich 111. Stanowi to ponad 90\% poświadczonych wyrazów. W rzeczywistości praca Ludwikowskiego i Walczaka to najbogatsze opracowanie socjolektu przestępczego.

Ciekawe jest to, że w słownikach pojawiają się różne warianty tych samych leksemów z alternacjami spółgłoskowymi (kirzyć - chirzyć, kipisz - chipisz) i samogłoskowymi (cebula - cybula, wytysz - witysz). Z jednej strony może to świadczyć o zróżnicowaniu regionalnym, $\mathrm{z}$ drugiej o tym, że socjolekt złodziejski był językiem mówionym, a następnie zapisanym tak, jak poszczególni badacze dany leksem usłyszeli. Taka sytuacja może także ukazywać proces adaptowania danych leksemów z obcych języków, tak jak w przypadku ksiwe - ksywa lub szorie passer - paser.

Analiza socjolektu przestępczego na podstawie „trylogii złodziejskiej” S. Piaseckiego okazuje się bardzo ciekawym zagadnieniem badawczym. Pozwala na wszechstronną charakterystykę środowiska przestępczego i na pełniejsze zrozumienie mechanizmów, które nim rządzą. Autentyczność mowy złodziejskiej zawartej w dziełach, a potwierdzonej przez opracowania leksykograficzne z przełomu XIX i XX w., w dużej mierze decyduje o wyjątkowości tych utworów.

13 Podczas analizy te hasła oznaczałam pismem pogrubionym.

14 Na przykład T. Szczerbowski (2018: 19-20) traktuje „trylogię złodziejską” jako nowe źródło haseł slangu złodziejskiego. Ponadto część haseł niepoświadczonych w wybranych przeze mnie do analizy słownikach znajduje się w innych (najczęściej późniejszych) polskich lub obcojęzycznych opracowaniach socjolektu przestępczego, por. m.in. Stępniak 1986, 2013; Bal'daev, Belko, Isupov 1992; Gorbacz 2006; Milewski 2009; Skarżyński 2015; Nevzorova-Kmech 2018. 


\section{Źródła}

E: K. Estreicher, Szwargot więzienny, Kraków - Warszawa 1903.

K: A. Kurka, Słownik mowy złodziejskiej, wyd. 2 zm. i rozsz., Lwów 1899.

LW: Żargon mowy przestępców „Blatna muzyka”: ogólny zbiór słów gwary złodziejskiej, oprac. W. Ludwikowski, H. Walczak, Warszawa 1922.

PiAsecki S., 1990a, Jabłuszko, Wrocław.

Piasecki S., 199ob, Spojrze ja w okno, Warszawa.

PiAsecki S., 1990c, Nikt nie da nam zbawienia, Warszawa.

Ud: S. Udziela, 1892, Żargon złodziejski we Lwowie, za: M. RAK, Kilka uwag o socjolekcie przestępczym polszczyzny przedwojennego Lwowa, „Socjolingwistyka” XXX, 2016, s. 133-145.

UŁ: H. Ułaszyn, Język złodziejski, „Łódzkie Towarzystwo Naukowe. Prace Wydziału I”, nr 11, Łódź 1951.

\section{Literatura}

BAL'DAEv D.S., BELKo V.K., Isupov I.M. (red.), 1992, Slovar' tûremno-lagerno-blatnogo žargona, Moskva.

Demel R., 2001, Sergiusz Piasecki (1901-1964): życie i twórczość, Warszawa.

Gorbacz O., 2006, Arg̀o v Ukraïni, Lviv.

Grabias S., 1997, Język w zachowaniach społecznych, wyd. 2 popr., Lublin.

Grabias S., 2010, Środowiskowe i zawodowe odmiany języka - socjolekty, [w:] J. Bartmiński (red.), Współczesny język polski, wyd. 3, Lublin, s. 235-253.

KoŁodziejeK E., 2015, Człowiek i świat w języku subkultur, wyd. 2 zm., „Rozprawy i Studia Uniwersytet Szczeciński”, t. 901, Szczecin.

Kubusiak E., 2018, Sergiusz Piasecki - człowiek pogranicza i jego język (na podstawie powieści Kochanek Wielkiej Niedźwiedzicy), [w:] R. Lipelt (red.), Na pograniczach: o stosunkach społecznych i kulturowych, „Na Pograniczach Kultur i Narodów”, t. 10, Sanok, s. 39-55.

Kurzowa Z., 2006, Język polski Wileńszczyzny i kresów pótnocno-wschodnich XVI-XX w., Kraków.

Labocha J., Tutak K., 2005, Podstawy analizy składniowej wypowiedzeń, „Jęzk, Tekst, Komunikacja”, Kraków.

LoEwe I., 2007, Gatunki paratekstowe w komunikacji medialnej, „Prace Naukowe Uniwersytetu Śląskiego w Katowicach", nr 2513, Katowice.

Mаєосна A., 1994, Żydowskie zapożyczenia leksykalne w socjolekcie przestęczym, [w:] J. Anusiewicz, B. Siciński (red.), Języki subkultur, „Język a Kultura”, t. 10, Wrocław, S. $135-170$.

Milewski S., 2009, Szemrane towarzystwo niegdysiejszej Warszawy, Warszawa.

Nevzorova-Kмесн E., 2018, Blatna muzyka („Żargon mowy przestępców”) F.V. Trachtenberga $i$ Żargon mowy przestępców. „Blatna muzyka”. Ogólny zbiór słów gwary złodziejskiej W. Ludwikowskiego i H. Walczaka (analiza porównawcza), „Acta Universitatis Lodziensis. Folia Linguistica Rossica” 15, s. 63-79, [on-line:] https://doi.org/10.18778/17318025.15.08.

Рієкот Т., 2008, Język w grupie społecznej: wprowadzenie do analizy socjolektu, Wałbrzych. 
Polechoński K., 200o, Żywot człowieka uzbrojonego: biografia, twórczość i legenda literacka Sergiusza Piaseckiego, Warszawa - Wrocław.

RAK M., 2016, Kilka uwag o socjolekcie przestępczym polszczyzny przedwojennego Lwowa, „Socjolingwistyka” XXX, s. 133-145.

Reychman J., 1965, Zapożyczenia tureckie w polskiej gwarze złodziejskiej, „Język Polski” XLV, s. $154-163$.

SKarżYŃski M., 2015, Rosyjskie липа, липовый i polskie lipa, lipny, „LingVaria” nr 10 (19), s. 195-204, [on-line:] https://doi.org/10.12797/LV.10.2015.19.13.

STĘPNIAK K., 1986, Słownik gwar środowisk dewiacyjnych, Warszawa.

STĘPNIAK K., 2013, Słownik gwar przestępczych, Kraków.

Szczerbowski T., 2018, Polskie i rosyjskie słownictwo slangowe, „Prace Monograficzne - Uniwersytet Pedagogiczny im. Komisji Edukacji Narodowej w Krakowie”, nr 869, Kraków.

Wilkoń A., 1987, Typologia odmian językowych współczesnej polszczyzny, „Prace Naukowe Uniwersytetu Śląskiego w Katowicach”, nr 865, Katowice.

\section{Criminal Sociolect in The Criminal Trilogy by Sergiusz Piasecki Summary}

The author of the article aims at reconstructing the criminal sociolect of the North-Eastern Borderlands in 1918-1919, based on The Criminal Trilogy by Sergiusz Piasecki. The plot of the novels takes place in Minsk Litewski, which, at that time, was full of thieves from all regions of Poland. In the novels, Piasecki recreated the sociolect of thieves living in the North-Eastern Borderlands, using the authentic criminal lexis. The authenticity of this sociolect is confirmed both by the materials provided by Piasecki himself (preface, footnotes and vocabulary of thieves' language) and by their comparison with other lexicographic scientific descriptions concerning criminal vocabulary from the first half of the twentieth century. 